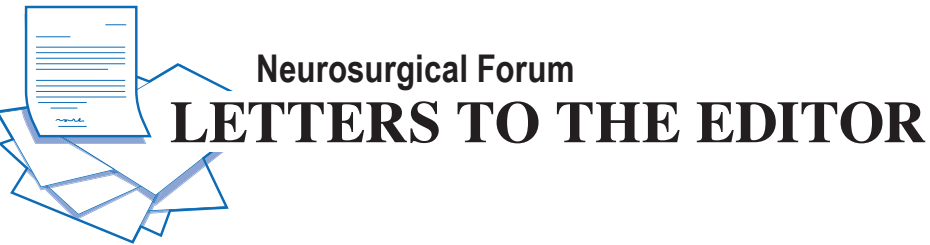

\section{How and why Hans Kraus, MD, helped President Kennedy's back pain}

TO THE EDITOR: We read with interest Drs. Pait and Dowdy's historical vignette ${ }^{6}$ (Pait TG, Dowdy JT: John F. Kennedy's back: chronic pain, failed surgeries, and the story of its effects on his life and death.J Neurosurg Spine 27:247-255, September 2017). We are personally connected to Dr. Hans Kraus (he was Dr. Ann Hansen's father and Dr. Norman Marcus' mentor and colleague), and we would like to take this opportunity to clarify the treatment program that was successful in restoring the president's musculoskeletal health.

When Dr. Kraus examined President Kennedy in October 1961, he made a diagnosis of weakness and stiffness of key postural muscles, and prescribed a therapeutic exercise program for gradual strengthening of weak muscles, and limbering or stretching to improve flexibility (Hans Kraus Personal Papers, John F. Kennedy Presidential Library and Museum; https://www.jfklibrary.org/AssetViewer/Archives/HKPP.aspx). In his words, "the essence of the program remains gradual and systematic re-training of muscles functioning below par." Dr. Kraus' program included judicious use of trigger-point injections as adjunctive interventions. Training activities such as swimming were later added to the program as tolerated. ${ }^{6}$

Dr. Kraus' method is based on his understanding of functional muscle pain. He classified muscle pain as follows: 1) muscle tension (related to stress); 2) muscle spasm (involuntary contraction of voluntary striated muscles); 3) muscle deficiency (weakness and/or stiffness); and 4) trigger points (resulting from sensitized muscle tissue and nociceptors) (Hans Kraus Personal Papers). ${ }^{2}$ Muscle tension is treated with relaxation exercises and medications; muscle spasm is best managed with tetanizing and rhythmic electrostimulation and gentle exercise using topical anesthesia (i.e., ice or ethyl chloride spray); muscle deficiency is treated with therapeutic exercise to improve strength and flexibility; trigger points are a chronic condition treated with injection followed by electrostimulation and therapeutic exercise.

Dr. Kraus' management of trigger points differs from the approach provided to JFK by Dr. Janet Travell, who had been injecting the president 5-6 times a day. Kraus' approach emphasized the following: 1) injections are only performed selectively based on a thorough patient evaluation that distinguishes among the 4 categories of muscle pain; 2) injections are one component of a comprehensive rehabilitation program; 3) postinjection therapeutic exercise emphasizes gentle motion aimed at restoring flexibility and local circulation, and does not include stretching; and 4) the injection is applied to the entirety of the affected muscle, with a focus on the entheses. We currently use the term Muscle Pain Amenable to Injection (MPAI) to distinguish this treatment modality from the more common simple trigger-point injection technique performed currently by most physicians and physical therapists in practices addressing musculoskeletal pain. ${ }^{4}$

Dr. Kraus' methods include a functional assessment, with the Kraus-Weber tests, of minimum strength and flexibility of key postural muscles, as well as muscular palpation with the patient prone and supine. Identifying the etiology of the functional muscle pain facilitates precise therapy, the success of which requires patient compliance with the tailored therapeutic exercise regimen that Kraus developed in the late 1940s at the Columbia-Presbyterian Hospital $^{1}$ and later successfully provided to 300,000 participants at the YMCA., ${ }^{3,5}$

Over the course of months, the president's condition steadily improved despite setbacks. Given the need for strict adherence to the therapeutic regimen, Dr. Kraus demanded an end to Dr. Travell's trigger-point injections and insisted that no other physicians be involved in the president's musculoskeletal care.7 By January 1963, President Kennedy understood the potential impact of Dr. Kraus' approach to the musculoskeletal health of the country. Based on JFK's personal history of failed back surgeries, suboptimal muscle injections, and successful treatment with Dr. Kraus' methods, he planned to establish a "National Foundation for Physical Fitness" to combat the progressive rise in the incidence of disabling back pain that appeared to be associated with overly sedentary American lifestyles (Hans Kraus Personal Papers).

Ann E. Hansen, DVM, MD

University of Washington School of Medicine, Boise Veterans Affairs Medical Center, Boise, ID

Norman J. Marcus, MD Weill Cornell Medicine, New York, NY 


\section{References}

1. Kraus H: Prevention of low back pain. J Occup Med 9: 555-559, 1967

2. Kraus H, Marcus NJ: The reintroduction of an exercise program to directly treat low back pain of muscular origin. $\mathbf{J}$ Back Musculoskelet Rehabil 8:95-107, 1997

3. Kraus H, Nagler W, Melleby A: An evaluation of an exercise program for back pain. Am Fam Physician 28:153-158, 1983

4. Marcus NJ, Shrikhande AA, McCarberg B, Gracely E: A preliminary study to determine if a muscle pain protocol can produce long-term relief in chronic back pain patients. Pain Med 14:1212-1221, 2013

5. Melleby A: The Y's Way to a Healthy Back. Piscataway, NJ: New Century, 1982

6. Pait TG, Dowdy JT: John F. Kennedy's back: chronic pain, failed surgeries, and the story of its effects on his life and death. J Neurosurg Spine 27:247-255, 2017

7. Reeves R: President Kennedy: Profile of Power. New York: Simon \& Schuster, 1994, pp 243-244

\section{Disclosures}

Dr. Hans Kraus was Dr. Ann Hansen's father.

\section{Response}

Dr. Hans Kraus played an important role in the rehabilitation of President John F. Kennedy's back and failed surgeries. Dr. Kraus, in conjunction with White House physician Dr. George C. Burkley and JFK's brother Robert Kennedy, helped engineer a White House medical coup d'etat that redirected the president's treatments away from more of a trigger point injection-based therapy to an exercise- and musculoskeletal rehabilitation-based program in the summer and fall of 1961. Without these therapeutic exercise programs for gradual muscle strengthening, Kennedy could not have astounded people with the physical stamina that his schedule demanded while in office (quoted material is all from John F. Kennedy Medical Records, Personal Papers, Box 11A, John F. Kennedy Presidential Library and Museum, Boston, MA).

Working with Jack Kennedy was often quite difficult. Dr. Kraus, feeling unappreciated and disturbed by the lack of regard for his expenses and bills, informed the president in October 1962 that he was ready to quit. He also expressed his disappointment regarding interest in a national fitness foundation and reconditioning program. In a communication on October 22, 1962, Dr. Kraus wrote: "I feel that my assignment had been accomplished and that it will be possible for the therapist whom I have carefully trained [to] continue under Dr. Burkley's direction. From now on it will be entirely at the discretion of the patient and Dr. Burkley when to request my visits."

Dr. Kraus' proposal for a National Foundation for Physical Fitness was ahead of its time. Dr. Kraus stated: "Medicine at large is interested in sickness-not health." He was an early pioneer and advocate of preventive medicine. Perhaps, if President Kennedy had had more time in office, this program would have been commissioned.

Evelyn Lincoln, secretary to the president, told Dr. Kraus after Kennedy's death: "I had full confidence in you, and I wasn't disappointed. From the very beginning I could notice increasing mobility and as a treatment progressed he was becoming a man with 'vigah.' I have often stated that in the last 6 months of President Kennedy's life he was in the best health he had ever been. And the thing he was able to do was to pick up little John and toss him around, something that had been lacking in his life. And all of this made possible because of your treatment."

On November 30, 1963, Dr. George Burkley sent Dr. Hans Kraus a letter that summed up his contribution to the health of President John F. Kennedy: "Just a note which in no way can express and convey the deep appreciation of your personal and professional value in the care of President Kennedy. Without your management the President would have been unable to carry on his active program which astounded the entire world. More important, you returned the President to a full life allowing him to enjoy the activities and sports he so dearly loved. You will always remain in the top of the list by those who dearly loved and worked with the President."

We thank Drs. Ann Hansen and Norman Marcus for sharing more about Dr. Kraus' contributions to the rehabilitation and maintenance of President Kennedy's spine problems and contributions to physical medicine and rehabilitation.

T. Glenn Pait, MD Jackson T. Stephens Spine and Neurosciences Institute, University of Arkansas for Medical Sciences, Little Rock, AR

Justin T. Dowdy, MD

Hot Springs Neurosurgery Clinic, Hot Springs, AR

\section{INCLUDE WHEN CITING}

Published online March 2, 2018; DOI: 10.3171/2017.9.SPINE17838.

CAANS 2018, except where prohibited by US copyright law

\section{John F. Kennedy's back: a few supplementary comments}

TO THE EDITOR: I read with interest the article by Pait and Dowdy ${ }^{9}$ (Pait TG, Dowdy JT: John F. Kennedy's back: chronic pain, failed surgeries, and the story of its effects on his life and death. J Neurosurg Spine 27:247255 , September 2017). In the accompanying editorial, Dr. Goodrich describes two bullet wounds to John F. Kennedy's (JFK's) head, not just one. Since the Warren Commission had conceded only one, it is gratifying to see this correction of the historical record. After a recent meticulous analysis of the medical and ballistic evidence, multiple headshots were found to be inescapable. ${ }^{4}$

Without sourcing their allegation, Pait and Dowdy name JFK as the initiator of the Vietnam War. On the contrary, an opposite consensus is now emerging among historians, as became evident (again) after the recent Vietnam War documentary by Ken Burns. ${ }^{1,2,6}$ If JFK had lived, we would not even recall a Vietnam War. JFK had decided to withdraw 1000 troops from Vietnam later that year; he had approved National Security Action Memorandum-263 on October 11, 1963. After the assassination, Lyndon Baines Johnson promptly reversed that decision, and so the war came. ${ }^{8}$

I would make the following points as well.

1) Pait and Dowdy describe an air myelogram, but they do not cite a Pantopaque procedure. Although it was well 
known before our (independent) visits, Michael Chesser, $\mathrm{MD}$, and I have both observed remnants of this dye in JFK's autopsy X-rays at the National Archives and Records Administration.

2) Although Pait and Dowdy cite some "excellent" literature articles, an excessive number are by John Lattimer, a urologist (none of the Dealey Plaza shots struck urologic sites), whose work has largely been debunked. ${ }^{10}$ The articles by Dennis Breo for the Journal of the American Medical Association won a Peter Lisagor Award, but that award later encountered stiff headwinds - and even a call for its retraction. ${ }^{5,7}$

3) An excellent article that should have been cited (but was not) is by L. R. Mandel. ${ }^{3}$

\section{David W. Mantik, MD, PhD} Rancho Mirage, CA

\section{References}

1. Dallek R: An Unfinished Life. John F. Kennedy, 19171963. New York: Little, Brown, 2003

2. Galbraith JK: JFK had ordered full withdrawal from Vietnam: solid evidence. WhoWhatWhy.org. September 26, 2017. (https://whowhatwhy.org/2017/09/26/jfk-ordered-fullwithdrawal-vietnam-solid-evidence/) [Accessed December 15, 2017]

3. Mandel LR: Endocrine and autoimmune aspects of the health history of John F. Kennedy. Ann Intern Med 151:350-354, 2009

4. Mantik DW: John F. Kennedy's Head Wounds. Seattle: Amazon Digital Services, 2015

5. Mantik DW: The Lisagor has no clothes. Chicago Reader. April 15, 1999. (https://www.chicagoreader.com/chicago/ the-lisagor-has-no-clothes/Content?oid=898945) [Accessed December 15, 2017]

6. McNamara RS, VanDeMark B: In Retrospect. The Tragedy and Lessons of Vietnam. New York: Vintage Books, 1995

7. Miner M: Autopsy of a Lisagor. Chicago Reader. March 4, 1999. (https://www.chicagoreader.com/chicago/autopsy-of-alisagor/Content?oid=898583) [Accessed December 15, 2017]

8. Newman JM: JFK and Vietnam: Deception, Intrigue, and the Struggle for Power. New York: Grand Central, 1992

9. Pait TG, Dowdy JT: John F. Kennedy's back: chronic pain, failed surgeries, and the story of its effects on his life and death. J Neurosurg Spine 27:247-255, 2017

10. Wallace M: Dr. Lattimer and the Great Thorburn Hoax. (http://www.assassinationweb.com/milam-thor.htm) [Accessed December 15, 2017]

\section{Disclosures}

The author reports no conflict of interest.

\section{Response}

We read with interest and curiosity the comments by Dr. Mantik regarding our article. As is well known, there is no shortage of disagreements between historians, government officials, experts, and would-be experts regarding the details surrounding the assassination of President Kennedy-these disputes are out of the scope of our research. Our overriding goal in researching the medical aspects of JFK's life and death was to focus primarily on peer-reviewed medical literature, along with the work of respected historians, and also personal review of restricted materials as research fellows at the John F. Kennedy Presidential Library and Museum. Simply put, the great majority of websites and popular press articles dealing with many aspects of Kennedy's life and death are the work of self-identified experts and conspiracy theorists that make for truly fascinating reading, yet fail to meet the more rigorous definitions of quality we felt appropriate for inclusion in our paper.

Although our paper's focus was not to investigate President Kennedy's role and long-term plans regarding the Vietnam conflict that he inherited from President Eisenhower, perhaps a clarification is in order. Biographer Robert Dallek quotes the president himself in a December 1962 press conference: "As you know, we have about 10 or 11 times as many men there (Vietnam) as we had a year ago." Dallek further sources the president's longtime close friend and advisor Kenneth O'Donnell, who recalled a conversation with JFK in May 1963 in which Kennedy "now agreed ... on the need for a complete withdrawal from Vietnam. 'But I can't do it until 1965-after I'm reelected."' Semantics aside, it's abundantly clear that Kennedy both accelerated the US involvement in Vietnam and yet also had serious reservations regarding this escalation and a strong desire to end American involvement after his planned re-election in 1964. ${ }^{1}$ The potential parallel outcome of the Vietnam conflict is yet another important unanswered question created by the fateful events of November 22, 1963.

Regarding Dr. Mantik's point about the myelogram procedure, it is unequivocally stated by naval neurosurgeon Dr. James White in a handwritten letter available at the John F. Kennedy Presidential Library and Museum in Boston that the diagnostic procedure prior to the first surgery (lumbar discectomy) in 1944 was indeed an air myelogram. This fact is also referenced by the team of physicians from the Mayo Clinic who were deeply involved in the management of then-Lt. Kennedy's spine care (John F. Kennedy Medical Records, Personal Papers, Box 11A, John F. Kennedy Presidential Library and Museum, Boston, MA). Although we encountered no evidence in our extensive research to support the claim that Kennedy ever underwent a Pantopaque myelogram, it's certainly possible that the president could have undergone this procedure at some point in his life (perhaps prior to his 1954 fusion procedure), which may explain Drs. Chesser and Mantik's findings in their review of the autopsy radiographs.

There is vast potential for disagreements regarding numerous aspects of JFK's life and death; however, one thing that we all can agree on is that John F. Kennedy's life and particularly his death will continue to captivate the collective consciousness of people from around the world.

Justin T. Dowdy, MD Hot Springs Neurosurgery Clinic, Hot Springs, AR

T. Glenn Pait, MD

Jackson T. Stephens Spine and Neurosciences Institute, University of Arkansas for Medical Sciences, Little Rock, AR

\section{References}

1. Dallek R: An Unfinished Life: John F. Kennedy, 19171963. New York: Little, Brown, 2003, pp 666-668

\section{INCLUDE WHEN CITING}

Published online March 2, 2018; DOI: 10.3171/2017.10.SPINE171117. 